\title{
Pembelajaran Daring Dalam Meningkatkan Motivasi dan Hasil Belajar Peserta Didik Selama Pandemi Covid-19: Sebuah Meta-Analisis
}

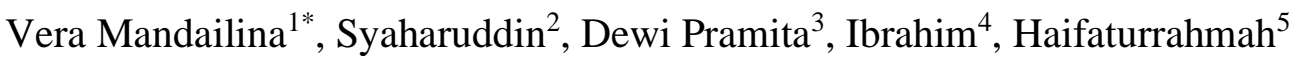 \\ 1,2,3 Pendidikan Matematika, Universitas Muhammadiyah Mataram \\ ${ }^{4}$ Pendidikan Geografi, Universitas Muhammadiyah Mataram \\ ${ }^{5}$ PGSD, Universitas Muhammadiyah Mataram \\ *e-mail: vrmandailina@gmail.com \\ (Received: 16-02-2021; Reviewed: 21-02-2021; Accepted: 01-03-2021)
}

\begin{abstract}
Abstrak
Dalam rangka mendukung kebijakan pemerintah untuk mengurangi penyebaran COVID-19, maka lembaga pendidikan diliburkan untuk proses pembelajaran secara langsung guna mendukung program social distancing. Salah satu mekanisme yang diterapkan adalah pembelajaran daring. Banyak penelitian dilakukan untuk mengetahui dampak positif dan negatif dari pembelajaran daring khususnya terhadap motivasi dan hasil belaajr peserta didik. Oleh sebab itu, tujuan dari penelitian meta-analisis ini adalah menganalisis kembali hasil-hasil penelitian atau publikasi ilmiah tersebut yang berkaitan dengan motivasi dan hasil belajar siswa selama pandemic COVID-19. Data dikumpulkan dari database pengindeks seperti Google Scholar, DOAJ, OneSearch, SINTA, dan Portal Garuda. Data yang difilter adalah hasil penelitian yang memuat nilai uji fisher $(\mathrm{F})$, uji student $(\mathrm{t})$, uji korelasi $(\mathrm{r})$, dan jumlah peserta didik $(\mathrm{N})$, kemudian dianalisis menggunakan meta-analisis melalui nilai effect size dan standart error untuk melihat summary effect size. Hasil analisis data menggunakan software JASP menunjukkan bahwa terdapat pengaruh yang signifikan pembelajaran daring dalam meningkatkan motivasi dan hasil belajar peserta didik sebesar 70\% dengan estimasi dampak sebesar 0,696 yang termasuk kategori sedang. Nilai ini menunjukan bahwa tentunya tidak sepenuhnya pembelajaran daring dapat meningkatkan motivasi dan hasil belajar siswa pada masa pandemi COVID-19, hal ini disebabkan dengan adanya beberapa factor kendala yang dihadapi selama proses pembelajaran daring baik oleh peserta didik, guru, maupun dosen.
\end{abstract}

Kata Kunci: Pembelajaran Daring; Motivasi Siswa; Hasil Belajar; Meta-Analisis

\begin{abstract}
In order to support government policies to reduce the spread of COVID-19, educational institutions are disbursed for the learning process directly to support social distancing programs. One of the mechanisms implemented is online learning. . Many studies are conducted to determine the positive and negative impact of online learning, especially on the motivation and results of learners. Therefore, the purpose of this metaanalysis research is to reanalyse the results of scientific publications related to students' motivation and learning outcomes during the COVID-19 pandemic. Data is collected from indexing databases such as Google Scholar, DOAJ, OneSearch, SINTA, and Garuda Portal. Filtered data is the results of research that contains fisher test values $(F)$, student test $(t)$, correlation test $(r)$, and number of learners $(N)$, then analyzed using meta-analysis through effect size and standart error values to see summary effect size. The results of the data analysis using JASP software showed that there was a significant influence of online learning in improving the motivation and learning outcomes of learners by $70 \%$ with an estimated impact of 0.696 belonging to the moderate category. This value shows that certainly not fully online learning can increase students' motivation and learning outcomes during the COVID-19 pandemic, this is due to several factors of obstacles faced during the online learning process by students, teachers, and lecturers.
\end{abstract}

Keywords: Online Learning; Student Motivation; Learning Outcomes; Meta-Analysis 


\section{PENDAHULUAN}

Bulan Maret 2020 dicatat sebagai awal mewabahnya virus (COVID-19) di Indonesia. Setiap hari jumlah pasien terkonfirmasi positif semakin bertambah. Terhitung sampai akhir 2020, terkonfirmasi positif sebanyak 719.219 orang, sembuh sebanyak 589.978 orang, dan meninggal sebanyak 21.452 (BNPB, 2020). Hal ini membuat pemerintah pusat sampai daerah menerapkan empat kebijakan yakni: (1) gerakan penggunaan masker, (2) penelusuran kontak (tracing) dari kasus positif, (3) edukasi masyarakat; dan (4) isolasi mandiri (Nurfurqon, 2020), (Suksmonohadi \& Indira, 2020). Dampak dari kebijakan ini mengeluarkan kebijakan baru seperti ditutupnya lokasi pembelanjaan, transportasi sampai lembaga pendidikan (Indriya, 2020).

Ditutupnya lembaga pendidikan atau pembelajaran secara offline merupakan kebijakan pemerintah untuk menghindari proses tatap muka secara langsung antara tenaga pendidik dan peserta didik (social distancing) (Huremović, 2019), (Rohmadani, 2020), (Qian \& Jiang, 2020). Hal ini dilakukan untuk mengurangi penyebaran COVID-19. Sehingga mulai dari perguruan tinggi sampai sekolah dasar (termasuk PAUD dan TK) memberlakukan pembelajaran dalam jaringan (daring). Proses belajar mengajar harus tetap mengoptimalkan penyampaian materi dengan baik guna menjaga kualitas hasil belajar termasuk peningkatan motivasi belajar peserta didik selama pandemik COVID19 (Saifulloh \& Darwis, 2020). Oleh sebab itu, setiap lembaga pendidikan mulai menerapkan pembelajaran daring menggunakan e-learning berbasis Moodle (Wicaksana et al., 2020), Google Classroom (Mulatsih, 2020), (Suhada et al., 2020), Zoom Meeting (Puspitorini, 2020), (Haqien \& Rahman, 2020), (Monica \& Fitriawati, 2020), Google Meet (Sawitri, 2020), (Purwanto \& Tannady, 2020), Quizizz (Wahyudi et al., 2020), Edmodo (Oktaviani et al., 2020), Youtube (Sari, 2020), dan aplikasi android lainnya.

Pembelajaran daring merupakan salah satu konsep dan teknologi di era 4.0. Teknologi ini menuntut para dosen dan guru berusaha untuk menguasai dan menerapkannya secara maksimal. Di sisi lain, peserta didik juga selain dituntut untuk menguasainya juga diperlukan tenaga dan biaya yang tidak sedikit karena berkaitan dengan waktu belajar dan kuota internet yang harus mereka gunakan selama proses pembelajaran, termasuk kekuatan jaringan internet atau sinyal di lokasi masing-masing peserta didik. Terlepas dari itu, hampir seluruh daerah di Indonesia menerapkan metode pembalajaran daring guna meningkatkan aktivitas belajar (Hasanah et al., 2020), motivasi belajar (Astuti et al., 2020), (Suryana et al., 2020), (Warmi \& Santoso, 2020), (Puspitaningsih \& Rachma, 2020), (Fadlilah, 2020), (Puteri et al., 2020), (Rosa, 2020), (Sugalang et al., 2020), (Puteri et al., 2020), (Hakim \& Mulyapradana, 2020), (Abdillah, 2020), (Sabila Hayati, 2020), (Fitriyani et al., 2020), dan hasil belajar siswa (Ashadii \& Suhaeb, 2020), (Ashadii \& Suhaeb, 2020), (Ferazona et al., 2020), (Tirtawati, 2020), (Maknuni, 2020), (Mirzon Daheri, Juliana, Deriwanto, 2020). Namun belum nampak sejauh ini bagaimana keberhasilan dari penerapan pembelajaran ini disetiap daerah di Indonesia. Karena setiap daerah memiliki karakteristik yang berbeda-beda baik dari sudut pandang peserta didik maupun fasilitas yang mereka gunakan seperti jaringan internet dan handphone yang mereka gunakan. Hasil-hasil penelitian ini hanya menjelaskan bahwa adanya peningkatan motivasi dan hasil belajar siswa, belum Nampak secara komultatif seberapa besar kekuatan pengaruh atau effect size dari seluruh penelitian tersebut. Meta-analisis merupakan solusi yang baik untuk mengetahui komultatif pengaruh-pengaruh tersebut dengan melihat effect size dan standar error setiap hasil penelitian sehingga bisa direpresentatifkan kepada populasi atau seluruh siswa di Indonesia. 
Oleh sebab itu perlu adanya analisis lebih lanjut dari hasil-hasil penelitian yang berkaitan dengan penerapan pembelajaran daring yang telah dilakukan selama ini oleh para dosen ataupun guru dalam meningkatkan motivasi dan hasil belajar siswa. Penelitian ini bertujuan untuk melihat tingkat keberhasilan pelaksanaan pembelajaran daring di Indonesia selama pandemik COVID-19.

\section{Metode}

Penelitian ini merupakan penelitian meta-analisis. Meta analisis adalah penelitian yang dilakukan peneliti dengan cara merangkum data penelitian, mereview dan menganalisis data penelitian dari beberapa hasil penelitian yang sudah ada sebelumnya. Adapun tahapan penelitian sesuai Gambar 1 .

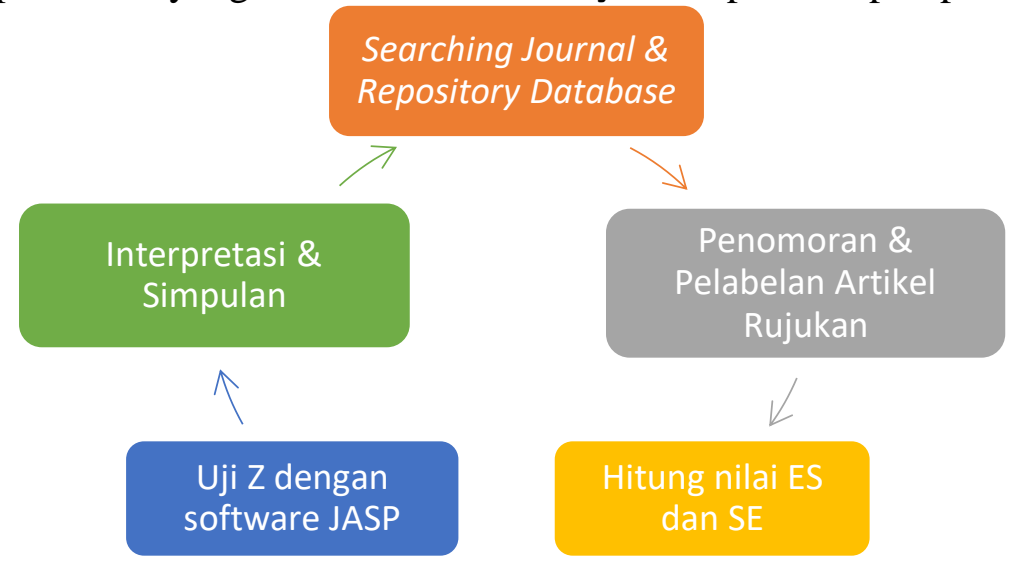

Gambar 1. Prosedur Penelitian

Pengumpulan data penelitian dilakukan peneliti dengan cara menelusuri (1) artikel-artikel yang terdapat pada jurnal terakreditasi nasional secara online, (2) hasil skripsi atau disertasi di repository, melalui database berikut:

1. Google Scholar: https://scholar.google.co.id/

2. Portal Garuda: http://garuda.ristekbrin.go.id/

3. Directory Of Open Access Journals: https://doaj.org/

4. Perpustakaan Nasional: https://www.onesearch.id/

Kata kunci yang digunakan peneliti dalam penelusuran artikel yakni (1) Variabel Bebas: Pembelajaran E-Learning, Pembelajaran Daring, Pembelajaran Android, Pembelajaran Online; (2) Variabel Terikat: Motivasi Belajar, Hasil Belajar; dan (3) Kata kunci tambahan: COVID-19 atau menggunakan interval pencarian tahun 2020-2021. Selanjutnya, analisis data dilakukan beberapa tahapan, yakni: (1) melakukan pelabelan atau penomoran artikel hasil seleksi; (2) menulis nilai uji Fisher (F), uji students (t), uji korelasi (r), dan jumlah subjek penelitian (N); (3) mengkonversi nilai $\mathrm{F}$ dan $\mathrm{t}$ ke nilai r; (4) menghitung nilai effect size (ES) dan standart error (SE); (5) melakukan analisis data berbantuan software JASP; (6) melakukan interpretasi terhadap hasil analisis data atau output dari software JASP; (7) menganalisis hasil-hasil yang ditemukan dari artikel-artikel yang menjadi rujukan data; (8) terakhir, mengambil kesimpulan dari hasil penelitian.

\section{Hasil}

Hasil penelusuran diperoleh data publikasi yang memenuhi sebanyak 18 publikasi. Data yang dikumpulkan dalam penelitian ini adalah nilai uji Fisher (F), uji student (t), uji korelasi (r), dan jumlah 
subjek penelitian $(\mathrm{N})$. Sedangkan metode atau media pembelajaran, serta jenjang dapat digunakan pada proses pembahasan atau analisis data lanjutan dengan ketentuan tambahan tertentu. Dari yang telah dikumpulkan masih terdapat nilai $\mathrm{F}$ dan $\mathrm{t}$. Kedua nilai ini harus dirubah menjadi nilai $\mathrm{r}$ menggunakan formula berikut.

$$
\begin{aligned}
& F=t^{2} \\
& t=\sqrt{F} \\
& r=\frac{t}{\sqrt{t^{2}+N-2}}
\end{aligned}
$$

Sehingga hasil perhitungan sesuai Tabel 1 berikut.

Tabel 1. Hasil Konversi Nilai F dan $\mathbf{t}$ ke $\mathbf{r}$

\begin{tabular}{rlllrrc}
\hline Kode & \multicolumn{1}{c}{ Penulis } & Jenjang & N & F & t & r \\
\hline J1 & Kurnianto, 2020 & SD & 28 & 4,925 & 0,69473 \\
\hline J2 & Viva, 2020 & SD & 40 & 2,494 & 0,37505 \\
\hline J3 & Kamaluddin, 2020 & SMP & 36 & 4,475 & 0,60883 \\
\hline J4 & Khailiani, 2020 & SMA & 27 & 1,139 & 0,22211 \\
\hline J5 & Wajong, 2020 & PT & 64 & 3,501 & 0,40628 \\
\hline J6 & Rianita, 2020 & PT & 130 & 19,359 & 0,86337 \\
\hline J7 & Ibrahim, 2020 & PT & 114 & 2,148 & 0,19891 \\
\hline J8 & Ahmad, 2020 & SMA & 140 & 18,47 & 4,2976 & 0,34357 \\
\hline J9 & Syarif, 2020 & SMA & 100 & 7,146 & 0,58529 \\
\hline J10 & Rodiyah, 2020 & SMP & 74 & 0,835 & 0,09793 \\
\hline J11 & Prabawa, 2020 & SD & 20 & 3,271 & 0,61058 \\
\hline J12 & Yusrizal, 2020 & SD & 50 & 23,476 & 0,95911 \\
\hline J13 & Samsul, 2020 & PT & 30 & 0,776 & 0,14510 \\
\hline J14 & Raga, 2020 & SMA & 60 & 9,373 & 0,77611 \\
\hline J15 & Yunus, 2020 & SD & 31 & & 0,62700 \\
\hline J16 & Ririn, 2020 & SD & 25 & & 0,59000 \\
\hline J17 & Wajong, 2020 & PT & 43 & 3,501 & 0,47974 \\
\hline J18 & Sulistiani, 2020 & SMP & 30 & 11,673 & 0,91080 \\
\hline
\end{tabular}

Setelah menemukan nilai z, maka dihitung nilai standart error (SE) menggunakan rumus:

$$
S E=\sqrt{\frac{1}{n-3}}
$$

Sehingga diperoleh nilai ES dan SE sesuai Tabel 2.

Tabel 2. Hasil Konversi Nilai ES dan SE

\begin{tabular}{clrrc}
\hline Kode & \multicolumn{1}{c}{ Penulis } & N & \multicolumn{1}{c}{ ES } & SE \\
\hline J1 & Kurnianto, 2020 & 28 & 0,857041 & 0,20000 \\
\hline J2 & Viva, 2020 & 40 & 0,394287 & 0,16440 \\
\hline J3 & Kamaluddin, 2020 & 36 & 0,70706 & 0,17408 \\
\hline J4 & Khailiani, 2020 & 27 & 0,225875 & 0,20412 \\
\hline J5 & Wajong, 2020 & 64 & 0,431148 & 0,12804 \\
\hline J6 & Rianita, 2020 & 130 & 1,306433 & 0,08874 \\
\hline J7 & Ibrahim, 2020 & 114 & 0,201597 & 0,09492 \\
\hline \multicolumn{7}{c}{123} & &
\end{tabular}




\begin{tabular}{clrrr}
\hline J8 & Ahmad, 2020 & 140 & 0,358135 & 0,08544 \\
\hline J9 & Syarif, 2020 & 100 & 0,670472 & 0,10153 \\
\hline J10 & Rodiyah, 2020 & 74 & 0,098245 & 0,11868 \\
\hline J11 & Prabawa, 2020 & 20 & 0,709846 & 0,24254 \\
\hline J12 & Yusrizal, 2020 & 50 & 1,93468 & 0,14586 \\
\hline J13 & Samsul, 2020 & 30 & 0,146131 & 0,19245 \\
\hline J14 & Raga, 2020 & 60 & 1,035513 & 0,13245 \\
\hline J15 & Yunus, 2020 & 31 & 0,736457 & 0,18898 \\
\hline J16 & Ririn, 2020 & 25 & 0,677666 & 0,21320 \\
\hline J17 & Wajong, 2020 & 43 & 0,522643 & 0,15811 \\
\hline J18 & Sulistiani, 2020 & 30 & 1,532198 & 0,19245 \\
\hline
\end{tabular}

\section{Pembahasan}

Selanjutnya, penulis melakukan uji hipotesis dan uji publication bias terhadap data yang sudah diperoleh. Dalam meta-analisis menggunakan software JASP yang dilihat dalam penarikan kesimpulan adalah nilai $z$ dan $p$-value pada tabel Coefficients. Adapun hipotesis sebagai berikut.

\section{Uji Hipotesis}

$H_{0}:$ true effect size $=0 \quad: \quad$ Pembelajaran berpengaruh meningkatkan

peserta didik pada masa pandemik COVID-19

$H_{1}$ : true effect size $\neq 0 \quad$ :
Pembelajaran

berpengaruh meningkatkan hasil belajar peserta didik pada masa pandemik COVID-19

\section{Uji Publication Bias}

daring tidak : Data sampel terindikasi

\section{dalam publication bias}

daring : Data sampel tidak dalam terindikasi publication bias

Berdasarkan hasil simulasi diperoleh output JASP sebagai berikut.

1. Uji Hipotesis

Uji hipotesis dapat dilihat berdasarkan nilai z dan p-value pada tabel output JASP sesuai Tabel 3.

Tabel 3. Output JASP Coefficients

\section{Coefficients}

\begin{tabular}{lcccc}
\hline & Estimate & $\begin{array}{c}\text { Standard } \\
\text { Error }\end{array}$ & $\mathbf{z}$ & p \\
\hline intercept & 0.696 & 0.118 & 5.876 & $<.001$ \\
\hline Note. Wald test. & & &
\end{tabular}

Pada Tabel 3 tentang coefficients di atas, terlihat nilai $z$ sebesar 5,876 dan nilai $p$-value sebesar 0,001 yang berarti lebih kecil dari nilai signifikansi $5 \%(0,05)$. Ini berarti hipotesis $\mathrm{H}_{0}$ ditolak, dalam hal ini true effect size tidak sama dengan 0, dengan kata lain pembelajaran daring 
berpengaruh signifikan terhadap motivasi dan hasil belajar siswa selama pandemik COVID19.

\section{Uji Publication Bias}

Uji ini dilakukan untuk melihat apakah data yang sudah terkumpul dapat dijadikan sampe yang representative dari populasinya. Uji ini dapat dilihat menggunakan nilai pada output Rank Correlation dan Regression Method

Tabel 4. Rank Correlation

Rank correlation test for Funnel plot asymmetry

\begin{tabular}{lcc}
\hline & Kendall's $\boldsymbol{\tau}$ & $\mathbf{p}$ \\
\hline Rank test & 0.157 & 0.363 \\
\hline
\end{tabular}

Tabel 5. Regression Test

\section{Regression test for Funnel plot asymmetry ("Egger's test")}

\begin{tabular}{ccc}
\hline $\mathbf{z}$ & $\mathbf{p}$ \\
\hline sei 0.192 & 0.847
\end{tabular}

Pada Tabel 4 terkait Rank correlation terlihat nilai Kendall's sebesar 0,157 yang menunjukkan besar koefisien korelasi antara effect size dengan varians. Kemudian nilai $p$-value sebesar 0,363 lebih besar dari nilai 0,05 yang menunjukkan bahwa hipotesis $\mathrm{H}_{0}$ ditolak dengan kata lain tidak terindikasi publication bias. Pada Tabel 5 terlihat nilai $z$ yang merupakan besarnya koefisien regresi sebesar 0,192, sedangkan nilai $p$-value sebesar 0,847 lebih besar dari 0,05 yang menunjukkan bahwa hipotesis $\mathrm{H}_{0}$ ditolak dengan kata lain Pembelajaran daring berpengaruh dalam meningkatkan hasil belajar peserta didik pada masa pandemik COVID19.

\section{Trim and Fill}

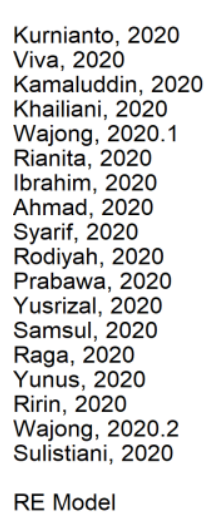

RE Mode
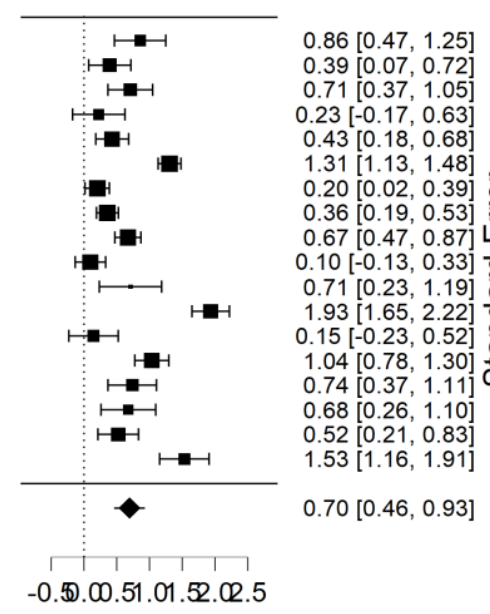

Gambar 2. Forest Plot

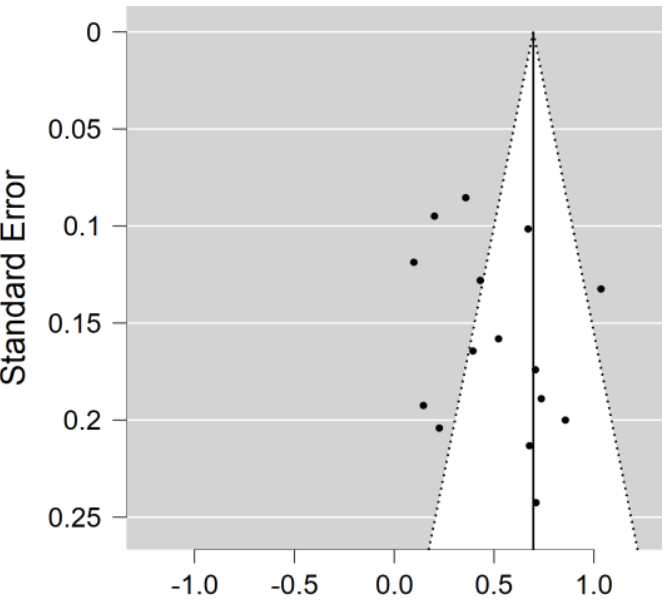

Berdasarkan hasil ploting publikasi pada Gambar 2 (sebelah kanan) dapat diketahui bahwa tidak ada penelitian yang hilang dengan ditandai lingkaran terbuka, seluruh lingkaran tertutup. Selanjutnya, dari gambar forest plot, diperoleh nilai summary effect sebesar 0,70. Nilai ini menjelaskan bahwa 
rata-rata pengaruh pembelajaran daring dalam meningkatkan motivasi dan hasil belajar peserta didik sebesar 0,70 atau 70\% yang termasuk kategori kuat. Sedangkan 30\% dipengaruhi oleh variabel lainnya. Tingkat persentase dan kategori dalam penelitian ini lebih tinggi dari hasil penelitian Hasanah et al (2020) dan Sur et al (2020) dengan kategori "sedang". Sedangkan penelitian Ferazona et al., (2020), Suryana et al (2020), dan Mustofa (2020) termasuk kategori baik atau kuat yang sesuai dengan hasil penelitian ini.

\section{Kesimpulan}

Pembelajaran daring sebagai upaya social distancing telah memberikan konstribusi yang cukup baik dalam memutuskan mata rantai penyebaran COVID-19. Berbagai hasil penelitian yang dianalisis membuktikan bahwa pembelajaran daring dengan berbagai sumber belajar online mampu meningkatkan motivasi dan hasil belajar siswa sebesar $70 \%$ yang termasuk kategori kuat. Terkait kendala-kendala yang dihadapi oleh guru, dosen, maupun peserta didik, baik dari sudut pandang fasilitas belajar maupun proses penyampaian materi pelajaran perlu perbaikan dan perhatian pemerintah secara optimal.

\section{Ucapan Terimakasih}

Tim penulis mengucapkan terima kasih kepada Lembaga Penelitian dan Pengabdian Masyarakat (LPPM) Universitas Muhammadiyah Mataram yang telah mendanai penelitian ini.

\section{Referensi}

Abdillah, R. H. (2020). Efektifitas BION (Bintang Online) Dalam Meningatkan Motivasi Belajar Siswa Pada Masa Pandemi Covid 19 di Kelas V SDN 1 Ngembel. Jurnal Pendidikan Dasar Nusantara, 6(1), 184-198. https://doi.org/10.29407/jpdn.v6i1.14674

Ashadii, N. R., \& Suhaeb, S. (2020). Hubungan Pemanfaatan Google Classroom dan Kemandirian terhadap Hasil Belajar Mahasiswa PTIK pada Masa Pandemi. Media Elektronik, 17(2), 46-51.

Astuti, W., Sur, A., Hasanah, M., \& Mustofa, M. R. (2020). Analisis Motivasi Belajar Mahasiswa dengan Sistem Pembelajaran Daring Selama Masa Pandemi Covid-19. EQUATION Teori Dan Penelitian Pendidikan Matematika , ISSN 2599-3291 (Cetak), ISSN 2614-3933 (Online), 3(2), 40-54.

BNPB. (2020). Statistik Perkembangan COVID-19 Indonesia. In Gugus Tugas Pecepatan Penanganan COVID-19 Republik Indonesia.

Fadlilah, A. N. (2020). Strategi Menghidupkan Motivasi Belajar Anak Usia Dini Selama Pandemi COVID-19 melalui Publikasi. Jurnal Obsesi : Jurnal Pendidikan Anak Usia Dini, 5(1), 373. https://doi.org/10.31004/obsesi.v5i1.548

Ferazona, S., Biologi, P., \& Riau, U. I. (2020). Pengaruh Pembelajaran Daring terhadap Hasil Belajar. Journal of Research and Education Chemistry, 2(2), 102-110.

Fitriyani, Y., Fauzi, I., \& Sari, M. Z. (2020). Motivasi Belajar Mahasiswa Pada Pembelajaran Daring Selama Pandemik Covid-19. Jurnal Kependidikan: Jurnal Hasil Penelitian Dan Kajian Kepustakaan Di Bidang Pendidikan, Pengajaran Dan Pembelajaran, 6(2), 165. 
https://doi.org/10.33394/jk.v6i2.2654

Hakim, M., \& Mulyapradana, A. (2020). Pengaruh Penggunaan Media Daring dan Motivasi Belajar Terhadap Kepuasan Mahasiswa Pada Saat Pandemik Covid-19. Widya Cipta: Jurnal Sekretari Dan Manajemen, 4(2), 154-160. https://doi.org/10.31294/widyacipta.v4i2.8853

Haqien, D., \& Rahman, A. A. (2020). Pemanfaatan Zoom Meeting untuk Proses Pembelajaran pada Masa Pandemi Covid-19. SAP (Susunan Artikel Pendidikan), 5(1). https://doi.org/10.30998/sap.v5i1.6511

Hasanah, A., Sri Lestari, A., Rahman, A. Y., \& Danil, Y. I. (2020). Analisis Aktivitas Belajar Daring Mahasiswa Pada Pandemi COVID-19. Karya Tulis Ilmiah (KTI) Masa Work From Home (WFH) Covid-19 UIN Sunan Gunung Djati Bandung Tahun 2020, 4-8.

Huremović, D. (2019). Social Distancing, Quarantine, and Isolation. In Psychiatry of Pandemics (pp. 85-94). https://doi.org/10.1007/978-3-030-15346-5_8

Indriya, I. (2020). Kebijakan Pemberlakuan Lockdown. SALAM: Jurnal Sosial Dan Budaya Syar-I, $7(3)$.

Maknuni, J. (2020). Pengaruh Media Belajar Smartphone Terhadap Belajar Siswa Di Era Pandemi ( The Influence of Smartphone Learning Media on Student Learning in The Era Pandemi. IDEAL : Indonesian Education Administration and Leadershio Journal, 02(02), 94-106.

Mirzon Daheri, Juliana, Deriwanto, A. D. A. (2020). Blended Learning Terhadap Hasil Belajar Di Era COVID-19: Pendekatan Meta-Analisis. Jurnal Basicedu, 3(2), 524-532.

Monica, J., \& Fitriawati, D. (2020). Efektivitas Penggunaan Aplikasi Zoom Sebagai Media Pembelajaran Online Pada Mahasiswa Saat Pandemi Covid-19. Jurnal Communio: Jurnal Jurusan Ilmu Komunikasi, 9(2), 1630-1640. https://doi.org/10.35508/jikom.v9i2.2416

Mulatsih, B. (2020). Penerapan Aplikasi Google Classroom, Google Form , Dan Quizizz Dalam Pembelajaran Kimia Di Masa Pandemi Covid-19. Ideguru: Jurnal Karya Ilmiah Guru, 5(1), 1626.

Mustofa, W. A. A. S. M. H. M. R. (2020). Analisis Motivasi Belajar Mahasiswa dengan Sistem Pembelajaran Daring Selama Masa Pandemi Covid-19 Analysis of Students ' Learning Motivation with Online Learning System during The Covid-19 Pandemic. Jurnal Equation IAIN Bengkulu, 3(2), 157-171.

Nurfurqon, A. (2020). Analisis Kebijakan Pemerintah Daerah Dalam Penanganan Covid-19: Perspektif Hukum Administrasi Negara. Jurnal Yustika: Media Hukum Dan Keadilan, 23(01), 13-23. https://doi.org/10.24123/yustika.v23i01.2864

Oktaviani, I., Waspada, I., \& Budiawati, N. (2020). Penerapan Media Pembelajaran E-Learning Berbasis Edmodo Pada Pembelajaran Daring Saat Pandemi COVID-19 (Ditinjau dari Persepsi Siswa). Jurnal IKA : Ikatan Alumni PGSD UNARS, 8(1), 68-78. 
Purwanto, E., \& Tannady, H. (2020). The Factors Affecting Intention to Use Google Meet Amid Online Meeting Platforms Competition in Indonesia. Technology Reports of Kansai University, 62(06), 2829-2838.

Puspitaningsih, D., \& Rachma, S. (2020). Persepsi Metode Pembelajaran Daring Dengan Motivasi Mahasiswa Sekolah Tinggi Ilmu Kesehatan Majapahit. Medica Majapahit.

Puspitorini, F. (2020). Strategi Pembelajaran Di Perguruan Tinggi Pada Masa Pandemi Covid-19. Jurnal Kajian Ilmiah, 1(1), 99-106. https://doi.org/10.31599/jki.v1i1.274

Puteri, W. A., Maharani, D. A., \& Wulandari, A. (2020). Penggunaan Media Audio Visual Untuk Meningkatkan Motivasi Belajar Siswa Selama Masa Pandemi Covid-19 Pada SD N 1 Serayu Larangan. ABDIPRAJA (Jurnal Pengabdian Kepada Masyarakat), 1(1), 122. https://doi.org/10.31002/abdipraja.v1i1.3146

Qian, M., \& Jiang, J. (2020). COVID-19 and social distancing. In Journal of Public Health (Germany). https://doi.org/10.1007/s10389-020-01321-z

Rohmadani, A. I. (2020). Dampak Covid 19 Terhadap Cara Berpikir Dalam Pembelajaran Daring: Studi Kasus di Yogyakarta. Edification Journal, 3(1), 125-134. https://doi.org/10.37092/ej.v3i1.224

Rosa, N. N. (2020). Hubungan Dukungan Sosial Terhadap Motivasi Belajar Daring Mahasiswa Pada Masa Pandemi COVID-19. TANJAK: Journal of Education and Teaching, 1(2), 147-153. https://doi.org/10.35961/tanjak.v1i2.146

Sabila Hayati, A. (2020). Peran Orang Tua dalam Meningkatkan Motivasi Belajar Anak Dengan Sistem Daring pada Masa Pandemi di Desa Depokrejo , Kebumen Arifia Sabila Hayati. Tasyri', $2,23-32$.

Saifulloh, A. M., \& Darwis, M. (2020). Manajemen Pembelajaran dalam Meningkatkan Efektivitas Proses Belajar Mengajar di Masa Pandemi Covid-19. Bidayatuna: Jurnal Pendidikan Guru Mandrasah Ibtidaiyah, 3(2), 285. https://doi.org/10.36835/bidayatuna.v3i2.638

Sari, L. (2020). Upaya Menaikkan Kualitas Pendidikan dengan Pemanfaatan Youtube Sebagai Media Ajar Pada Masa Pandemi Covid-19. Jurnal Tawadhu, 4(1), 1074.

Sawitri, D. (2020). Penggunaan Google Meet Untuk Work From Home Di Era Pandemi Coronavirus Disease 2019 (Covid-19). Prioritas: Jurnal Pengabdian Kepada Masyarakat, 2(01), 13-21.

Sugalang, G. A., Yusuf LN, S., Suprianto Ahmadi, R., \& Febrian, F. (2020). Model Strategi ELearning Terhadap Motivasi Belajar Mahasiswa di Masa Wabah COVID-19. Ekono Insentif, 14(2), 120-128. https://doi.org/10.36787/jei.v14i2.266

Suhada, I., Kurniati, T., Pramadi, A., Listiawati, M., Biologi, P. P., Gunung, S., \& Bandung, D. (2020). Pembelajaran Daring Berbasis Google Classroom Mahasiswa Pendidikan Biologi Pada Masa Wabah Covid-19. Digital Library UIN Sunan Gunung Jati, 2019, 1-9. 
Suksmonohadi, M., \& Indira, D. (2020). Kebijakan Penanganan Pandemi Covid-19. Perkembangan Ekonomi Keuangan Dan Kerja Sama Internasional, Edisi II, 89-112.

Sur, W. A. A., HasanahMinhatul, \& Mustofa, M. R. (2020). Analisis Motivasi Belajar Mahasiswa dengan Sistem Pembelajaran Daring Selama Masa Pandemi Covid-19. EQUATION Teori Dan Penelitian Pendidikan Matematika , ISSN 2599-3291 (Cetak), ISSN 2614-3933 (Online), 3(2), 40-54.

Suryana, Y., \& dkk. (2020). Manajemen Pembelajaran Daring Berbasis Empati untuk Pemeliharaan Motivasi Belajar Daring Mahasiswa dalam Situasi Wabah COVID-19. Digital Library, UIN SUnan Gung Djati, Bandung, 1-14.

Suryana, Y., Sanusi, H. P., Hermawan, A. H., \& Hidayat, W. (2020). Manajemen Pembelajaran Daring Berbasis Empati Untuk Pemeliharaan Motivasi Belajar Daring Mahasiswa Dalam Situasi Wabah Covid-19. Digital Library, UIN SUnan Gung Djati, Bandung, March, 1-14.

Tirtawati, N. L. R. (2020). Isolasi Mandiri Covid-19 dengan Daring PjBL Berbasis Mind Mapping untuk Meningkatkan Hasil Belajar Biologi. Journal of Education Action Research, 4(4), 393. https://doi.org/10.23887/jear.v4i4.28504

Wahyudi, W., Rufiana, I. S., \& Nurhidayah, D. A. (2020). Quizizz: Alternatif Penilaian di Masa Pandemi Covid-19. Jurnal Ilmiah Soulmath : Jurnal Edukasi Pendidikan Matematika, 8(2), 95. https://doi.org/10.25139/smj.v8i2.3062

Warmi, A., \& Santoso, E. (2020). Motivasi dan Kemandirian Belajar Siswa Pada Mata Pelajaran Matematika di Masa Pandemi Covid-19. Jurnal Education and Development, 8(3), 196.

Wicaksana, E. J., Atmadja, P., Lestari, W., Tanti, L. A., \& Odrina, R. (2020). Efektivitas pembelajaran menggunakan moodle terhadap motivasi dan minat bakat. EduTeach: Jurnal Edukasi Dan Teknologi Pembelajaran, 1(2), 117-124. 